Available online on 15.09 .2018 at http://jddtonline.info

Journal of Drug Delivery and Therapeutics

Open Access to Pharmaceutical and Medical Research

JDDT

C) 2011-18, publisher and licensee JDDT, This is an Open Access article which permits unrestricted non-commercial use, provided the original work is properly cited

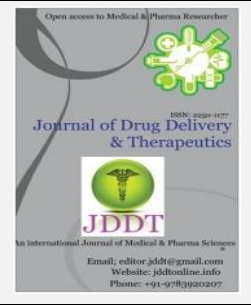

Open $\odot$ Access

Review Article

\title{
The Traditional Approaches for the Management of Mental Diseases W.S.R. to Indigenous Herbs in Manovikara
}

\author{
Dr. Chaitanya H. Vaidya \\ Lecturer, Kaya Chikitsa Department, Jupitar Ayurved Medical College, Nagpur, India
}

\begin{abstract}
The uses of ayurveda not only reside around as main stream of ancient science but it also served as complementary or alternate medicine. Ayurveda provides principles to maintain good healthy status of mind, body and soul. Ayurveda also offer therapies for the management of mental health issues including; shodhna therapy, use of herbs \& formulation and yoga therapy. The use of indigenous herbs \& plants greatly recommended by ancient acharya in mental illness such as; Bacopa monnieri, Centella asiatica, Amla, Mucuna, Zizyphus jujube, Kava and Saffron. This article describe role of indigenous herbs and traditional medicine in the management of mental problems.
\end{abstract}

Keywords: Ayurveda, Mental Health, Kaya-Chikitsa, Indigenous Herbs and Swasthya.

Article Info: Received 12 June, 2018; Review Completed 13 Aug 2018; Accepted 20 Aug 2018; Available online 15 Sep 2018

Cite this article as: Vaidya $\mathrm{CH}$, The Traditional Approaches for the Management of Mental Diseases W.S.R. to Indigenous Herbs in Manovikara, Journal of Drug Delivery and Therapeutics. 2018; 8(5):104-106

DOI: http://dx.doi.org/10.22270/jddt.v8i5.1867

\section{INTRODUCTION}

Ayurveda treat disease by pacifying these factors which may vitiate during pathological conditions. Ayurveda recommends various approaches for healthcare management such as; good conduct of dietary and lifestyle habits (Ahara-Vihara), yogic exercises, herbal treatment and shodhna therapy ${ }^{1-3}$. The swasthya (good health) depends upon following elements:

- Balances of psychological elements (samadosha)

- Proper production of energies (samagnischa)

- Balances of tissues (samadhatu)

- Proper elimination of wastes (malakriya)

- Happy soul (prasannatma)

- Prasanna-manaha and sama-indriya.

These all elements along or combining with each other helps an individual to remain healthy and happy ${ }^{2-6}$.

The Manas, Sarira, Atma and Indriya mainly constitute human body. The balancing of psychological senses (Gyanendriya) and physical organs (Karmendriya) contributes greatly towards the healthy regimen, therefore we can say that healthy well being not only depends upon physical compatibility but also depends upon good status of Manas.

The Manas associated with Gunas such as; Satva, Rajas and Tamas which define characteristics of an individual as follows:

* Satva guna represents knowledge, self control and differentiation power.

* Rajas guna related to motion, envious, violent, authoritative, desirous and confused.

* The Tamas guna associated with dullness, lazy behavior and drowsiness.

The imbalance of Manodoshas; Satva, Rajas and Tamas are mainly considered responsible for mental illness; Manovikara. The psycho-biological elements: Vata, Pitta and Kapha known as tridoshas which need to be in balancing condition for maintaining good health, the tridoshic imbalance leads diseases pathogenesis and as per ayurveda mental disease may also occur due to the tridoshic imbalance associated with other factors such as misrepresentation of Manodoshas. 


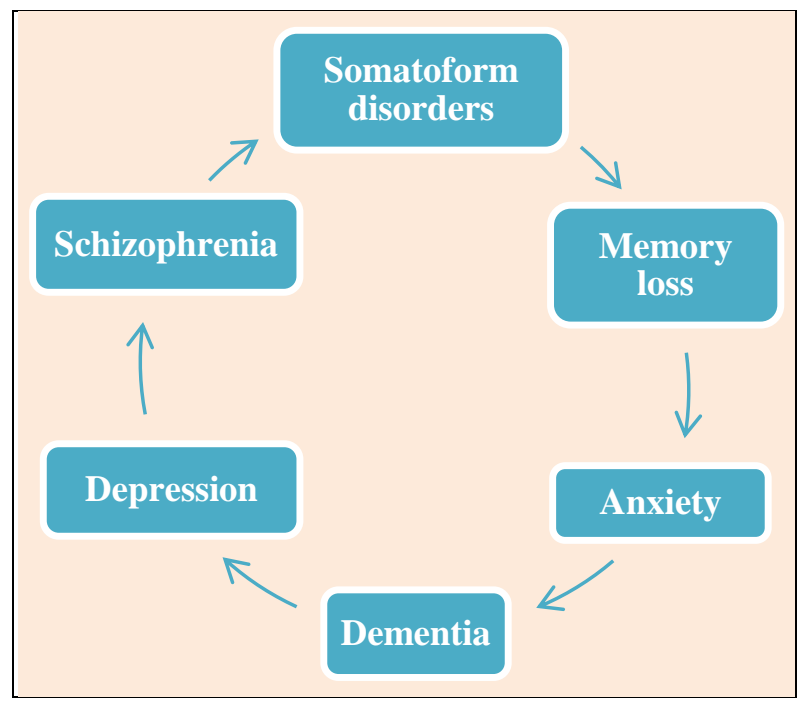

Figure 1: Common mental illness

The obsessive-compulsive, psychosis, bipolar depression, phobia, anxiety and memory loss, etc. are the major disease categorized under mental illness. The mental disorders characteristically involves changed in psychological pattern, behavior problems, mental distress or disability and misrepresentation of feels, acts, thinks or perceives. Ayurveda recommended following major approaches for the management of mental illness:

* Samshamana which balances the doshas and gunas,

* Use of Rasayana which strengthens mental power,

* Use of herbs and formulations which offer relief at root cause of disease while use of

* Yoga along with good conduct of Ahara-Vihara not only helps to treat mental illness but also prevent recurrences of such diseases.

The literature survey revealed that the various indigenous herbs and plants contributed greatly towards the management of mental illness. Kava may be used in the treatment of anxiety and depression, Rhodiola rosea (roseroot) and saffron in depression while passion flower and scullcap may be used in anxiety ${ }^{3-7}$.

Some herbs and natural drugs used in mental illness are as follows ${ }^{5-10}$ :

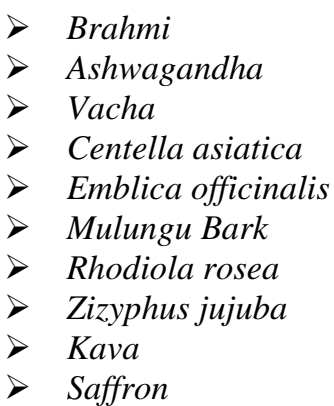

\section{Brahmi (Bacopa monnieri):}

It is a nerve-rejuvenating herb used anciently in condition in which brain function declined and psyche related disorders. It also used in epilepsy attacks, acts as non-sedative tranquillizer therefore recommended in anxiety and hypertension. Bacopa monnieri prevents dopaminergic neuro-degeneration and may be used in parkinson's disease. It may also recommend in Alzheimer's disease.

\section{Ashwagandha (Withania somnifera):}

It's mainly maintains functioning of Vata when it get aggravated. The Ashwagandha helps to stabilize vata which converts cold vata to hot vata. Ashwagandha offers good effect on nervous system, circulatory system and physiological functioning. Ashwagandha helps to suppress anxiety and hypertension. It relieves stresses; improve immunity and overall strength of body. Treating mental fatigue, depression and boost memory functioning.

\section{Vacha (Acorus calamus):}

It comes under Medhya Rasayana used as restorative, nervine and mental tonics. Acts on central nervous system, improve grasping power, memory, intellect and speech. Vacha helps to balances emotions and mood.

\section{Centella asiatica (Gotu Kola):}

Centella asiatica acts as effective brain promoter, it offers health benefits in mental fatigue, depression, anxiety, memory loss and insomnia. It improved selfrated mood, treat decline in cognitive function and offer excellent effects in mentally-deficient children.

\section{Emblica officinalis (Amla):}

Amla promote intelligence and memory. It is an important ingredient of one of the mental tonic chyawanprash, the tannins present in Amla help to manage free radical pathology in brain. It lowers damage of brain cell membrane, Vitamin C of Amla offers antioxidant activities, and it possesses neuro-protective effects in seizures. Amla may be used as supplements for brain health to sharpen the thinking ability \& focusing power, it also improves memory retention power of brain.

\section{Rhodiola rosea:}

This herb known to have beneficial effects to the brain health since it contains salidroside which act as antioxidant agent and other compound rosin reduce inflammation of neural cells thus protect against neurotoxicity. The herb reduces mental fatigue, improved mood and control stress.

\section{Zizyphus jujube:}

Zizyphus jujuba support mental health, boost energy levels and good for mental strength. The saponins present in herb offers sedative and relaxing effects.

\section{Saffron:}

Saffron improves mood, relieves stress and anxiety. It also offers calming effects, elevates suppressed mood and boost mental performances. 
Table 1: Role of some indigenous herbs in the management of mental illness

\begin{tabular}{|c|c|c|c|}
\hline S. No. & $\begin{array}{l}\text { Herbs } \\
\text { (Botanical name) }\end{array}$ & $\begin{array}{l}\text { Herbs } \\
\text { (Hindi name) }\end{array}$ & Uses in mental illness \\
\hline 1 & Acorus calamus & Adusa & $\begin{array}{l}\text { It enhances memory, offers beneficial effects in anxiety, epilepsy } \\
\text { and facial paralysis. }\end{array}$ \\
\hline 2 & Calamus & Safed vasa & $\begin{array}{l}\text { It helps in forgetfulness. It also offers benefits in anxiety and } \\
\text { epilepsy. }\end{array}$ \\
\hline 3 & Anacyclus pyrethrum & Akarkara & $\begin{array}{l}\text { Controls intensity of hysteria, controls epilepsy, improves mental } \\
\text { retardation and boost mental functioning. }\end{array}$ \\
\hline 4 & Cannabis sativa Linn & Bhang & $\begin{array}{l}\text { Its leaves used for epilepsy type problem and it also help to treat } \\
\text { sleeplessness. }\end{array}$ \\
\hline 5 & Cassia occidentalis & Kasaundi & Relieves epilepsy and hysteria. \\
\hline 6 & Citrullus colosynthis & Indrayan & Cures migraine and Nasya of its root powder used for epilepsy. \\
\hline 7 & $\begin{array}{l}\text { Convolvulus } \\
\text { microphyllus }\end{array}$ & Shankahuli & $\begin{array}{l}\text { Its powder with bach improve memory power, its juice helps to } \\
\text { manage epilepsy, psychosis and insanity. Its powder strengthens } \\
\text { the mental functioning. }\end{array}$ \\
\hline 8 & Cyperus scariosus & Nagarmotha & It recommended for epilepsy with cow milk. \\
\hline 9 & Glycyrrhiza glabra & Mulethi & Powder in ghee offer improvements in epilepsy. \\
\hline
\end{tabular}

\section{CONCLUSION}

The literature study revealed that traditional Ayurvedic medicine supports brain functions, boost memory, manage cognition and improves brain activities. The ancient system of medicine Ayurveda described that various mental illness such as; depression, parkinson's disease, hysteria, anxiety, memory loss, migraine, insomnia and Alzheimer's disease may be treated by using various indigenous herbs. These herbs boost memory, improve mental function and restore cognition. Bacopa monnieri, Centella asiatica, Amla, Mucuna, Zizyphus jujube, Kava and Saffron are some important herbs recommended for the management of mental illness. The article finally concluded that various

\section{REFERENCES}

1. Dwivedi V.N., "Ayurved $\mathrm{Ki}$ oushadhiya Va unka vargeekaran", Institute for Ayurvedic studies and Research, Jamnagar, - 18, 1966.

2. Acharya Y.T., "Sushrutasamhita", Nirnayasagar Press. Bombay, 227, 1938.

3. Chatterjee-Acharya P., "My experiments with Cuckoo meat", Journal of Research in Indian Medicine, 1972; 2:79.

4. Agarwal V, Abhijnhan A, Raviraj P. Ayurvedic medicine for schizophrenia. Cochrane Database of Systematic Reviews, 3, 2010.

5. World Health Organization. Legal Status of Traditional Medicine and Complementary/Alternative Medicine: A Worldwide Review. 2001. indigenous herbs along with other approaches of alternative therapies should be recommended for the management of mental disorders with lesser chances of side effects.

Ayurveda also recommended some formulations in mental diseases which are as follows:

- Ksirabala taila

- Dhanvantara taila

- Asanabilvadi taila

- Kusmandarasayana

- Cyavanaprasa

- Satavari leha
6. Savnur H.V. A Handbook of Ayurvedic Materia Medica. Vol.1 Dr. Jarthar and Sons, Maruthi Street, Belgaum Karnataka India, 1950.

7. Rao RV, Olivier D, John V, Bredesen DE, Ayurvedic medicinal plants for Alzheimer's disease: a review. Alzheimer's Res Ther, 2012; 4:22-30.

8. Younus M, Younus A, Shahbaz I, Value of Ayurvedic medicinal plants as psychotherapeutic agents-A review. Intern J Innov Sci Engg Tech 2015; 2:144-148.

9. Lavretsky H, Complementary and alternative medicine use for treatment and prevention of late-life mood and cognitive disorders. Aging Health 2009; 5:61-78.

10. Curatolo P, D'Agati E, Moavero R, The neurobiological basis of ADHD. Ital J Pediatr 2010; 36:79-85. 